conducted for the Third Statistical Account of Scotland.

Grants from the Oliver Bird Fund, totalling $£ 48,800$, have been allocated for a programme of research on cortisone, the pituitary adreno-corticotrophic hormone and similar substances, as well as a further $£ 8,825$ for other researches into rheumatism. In this work the Foundation is maintaining the closest possible liaison with the Medical Research Council, and representatives of the pharmaceutical industry have been approached with a view to even wider collaboration, by pooling the results of commercial and academic research upon the problems presented by cortisone and adreno-corticotrophic hormone. This programme comprises a grant of $£ 1,000$ for apparatus and $£ 10.000$ over three years to the School of Biochemistry, Cambridge, for work on the isolation and purification of the pituitary adrenocorticotrophic hormone, its fission into peptides, and a study of their composition, structure and synthesis, as well as $\mathfrak{f 5 , 0 0 0}$ over three years to the University Chemical Laboratory for research on the synthesis of biologically active related peptides and on the synthesis of compounds with cortisone-like activity. $£ 10,000$ for three years has been granted to the Dyson Perrins Laboratory, Oxford, for a project for the partial or total synthesis of cortisone and analogous substances, and $£ 1,000$ for two years to the School of Chemistry, Royal Technical College, Glasgow, for an investigation of materials other than bile-acids as a source of cortisone-like substances.

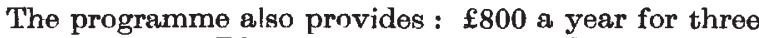
years to the Rheumatism Research Centre, Man. chester, for technical assistance in recording cliniophysiological data on the effect of cortisone and adreno-corticotrophic hormone; $\$ 5.000$ over three years to the Department of Biomolecular Structure, Leeds, for intensive examination of arthritic lesions supplied by the Rheumatism Research Centre; and $£ 10,000$ over five years to the research unit to be set up by the Department of Medicine, St. Mary's Hospital School, London, for study of the action of cortisone and adreno-corticotrophic hormone on various other disease states.

New grants for fundamental research in the biological sciences include $\mathfrak{\$ 8 . 2 5 0}$ over five years to the Department of Zoology, King's College, London, for the study of the differentiation between cell-types by nuclear and cytoplasmic transplantation, and by cytochemical methods; $£ 10,000$ to the Department of Anatomy, University College, London, for a fiveyear continuation of the research into the physiolngy of learning and the addition of an electronic engineer to the Department; $£ 15,000$ for five vears to the Laboratory of Chemical Crystallography, University of Oxford, for the formation of a research unit equipped with calculating machinery and computing assistance for the X-ray analysis of crystals of complex compounds; and $£ 12,000$ over five years to the trustees of the Strangeways Research Laboratory, Cambridge, for research on the structure and physiology of living cells, with special reference to the problems of cell division, and experimental investigation into the processes of cellular differentiation.

In the sociological field, the Foundation has provided $£ 6,000$ for an inquiry over three years by the Department of Economics, Aberdeen, into the budgets of young childless couples, married couples having their first child and married couples having their second baby, as well as $£ 12,000$ over three years for a systematic research, in collaboration with the
Tavistock Institute of Human Relations, on the development of various patterns of family life and the relative contribution of individuals and com. munity to these patterns. A grant of $£ 10,000$ has been promised to the London School of Economics and Political Science to meet for five years staff salaries for the new Division of Research Techniques. The principel concern of the Division will be research in the application of statistical techniques to social data and the study of sampling and interviewing techniques. A grant of $£ 5,000$ has also been made to the joint mental-survey committee of the Population Investigation Committee and the Scottish Council for Research in Education to follow the careers of the 12,000 sample children for the five-year stage until they reach eighteen years of age.

For the first stage of an investigation into the consistency of stop-watch time studies, to be conducted with a steering committee under the chairmanship of Sir Frederic Bartlett, the Foundation has set aside $£ 2,000$. The dental fellowships and scholarships and the Dominion travelling fellowships schemes are continued unaltered, but a new scheme of United Kingdom medical fellowships has been instituted, under which the emphasis is changed to future teachers and research workers. A new scheme of travelling fellowships for the Home Civil Service has been introduced, under which three fellowships a year are offered to Civil servants at the prineipal and assistant-secretary levels-and equivalents in the scientific grades-to visit other parts of the British Commonwealth for six months to a year. The first selection took place in March 1950.

Finally, there is foreshadowed in the report a scheme for extending the Nuffield Foundation Dominion travelling-fellowships-already in operation for Australia, Canada, South Africa and New Zealand-to the new Dominions of Ceylon, India and Pakistan. Since the report was published it has been announced that the following awards have been made : Ceylon, one fellowship (in medicine); India, five fellowships (two in medical sciences, and one each in engineering, natural sciences, and social sciences); Pakistan, three fellowships (subjects not yet selected). The object of the travelling-fellowships, which are open to men and women graduates, is to advance the interests of the new Dominions and to strengthen further their academic ties with the United Kingdom. The fellowships last for one year, and, according to whether the holder is married or single, are worth $£ 770-890$, in addition to travelling expenses (for a wife as well) to and from Great Britain.

\section{COTTON RESEARCH STATION, NAMULONGE, UGANDA}

$\mathrm{A}^{\mathrm{s}}$

S announced in Nature of November 18 (p. 850), the Parnell Laboratories at the Empire Cotton Growing Corporation's new Cotton Research Station at Namulonge, near Kampala, Uganda, were officially opened by H.E. Sir John Hathorn Hall, Governor of Uganda, on November 9. Among the large gathering of guests who witnessed the ceremony were H.H. the Kabaka of Buganda and the Nabagereka, Sir John and Lady Russell, Dr. and Mrs. B. A. Keen, Dr. H. H. Storey, and Mr. G. W. Nye, representing the Secretary of State for the Colonies. Mr. F. R. Parnell, the first director of the Station, and Mrs. Parnell 
were present, and also Mr. Arrowsmith, of the Raw Cotton Commission, Mr. Killick, of the Cotton Board, the directors of agriculture or their representatives from Kenya, Nyasaland, Tanganyika and Uganda, the director of agriculture and the chief of the Research Division from the Sudan, representatives from the Belgian Congo and French territories in Africa, and senior research officers of the Corporation from the Sudan, Tanganyika and Nyasaland.

The Namulonge Station, the director of which is Dr. J. B. Hutchinson, comprises 2,240 acres of land, excellently situated for experimental work on cotton and the food crops associated with it in the Buganda agricultural system. Ten staff houses and a guest house have been completed and occupied, and three more are in course of construction. The laboratory block was named by H.E. the Governor after Mr. F. R. Parnell, the first director. The building is designed to accommodate twelve research officers and to provide facilities for visiting workers and research students.

The day following the official opening was devoted to technical discussions and tours of the field experiments. In the afternoon, the first meeting of the African Advisory Board of the Station was held and was attended by directors of agriculture and senior research officers from Kenya, Tanganyika, Nyasaland, Uganda and the Sudan. The first progress report of the station was received, and the research programme discussed.

Research is planned in crop husbandry and physiology, entomology, plant pathology and plant breeding and genetics. Crop husbandry work will be concerned primarily with the task of fitting cotton into a balanced farming system, in which native food crops, grass-resting leys, and stock keeping will all have their place. Cotton physiology studies will start from a consideration of the crop environment, and comprehensive meteorological data are being collected. Work on the effect of water and nutrient supply and of leaf area on plant development and cropping capacity will follow, and will be linked up with studies on the physiology of lint development, and the genetic and environmental control of cotton quality.

The entomological programme includes studies of the bionomics of cotton pests, fundamental investigations in insect physiology, and work on the tech. nique of pest control by insecticides. This last will be carried out jointly with the East African Agricultural and Forestry Research Organization.

The main problems in plant pathology are those of the epidemiology of bacterial blight, and of wilt diseases. The practical solution to both types of disease lies in the breeding of resistant varieties ; but progress in breeding work will be slow and uncertain until the factors governing outbreaks of disease are understood, and the physiology of resistance has been elucidated.

Plant-breeding work includes the breeding and first multiplication of pedigree stocks of the commercial Uganda variety $B P 52$, the transfer of genes conferring resistance to bacterial blight to East African commercial stocks, and the synthesis of heavy-cropping stocks for further selection at territorial stations.

Long-range genetical research is carried on at Shambat, near Khartoum in the northern Sudan, by arrangement with the Sudan Government. The maintenance of the very extensive C.R.S. collection of the world's cottons, and of wild species of Gos. sypium, is easier under the irrigated conditions of the northern Sudan than under rain-fed cropping in Uganda, and the possibility of growing two genera. tions a year increases the rate of progress in genetic research.

At the meeting of the Advisory Board, discussion centred around the allocation of cotton research problems between territorial stations and Namulonge, and agreement was reached on general principles, and on detailed arrangements as they affect the Namulonge programme for the coming year.

\section{NEW AUSTRALIAN HOUSE AT KEW}

$T$

HE flora of Australia is certainly one of the most interesting and scientifically important floras of the world. It is naturally an extensive one, though when George Bentham produced at Kew the "Flora Australiensis" between the years 1863 and 1878, its seven volumes contained descriptions of less than nine thousand species of vascular plants, a number far exceeded by the known flora of to-day. For example, in the genus Acacia alone Bentham recorded 293 species compared with nearly twice that number now known to botanists. It is a flora notable for the rich representation of such families as Proteaceæ, Myrtaceæ and Rutaceæ and such genera as Hibbertia and Drosera, with a wealth of endemics that are fitting parallels to the marsupials and monotremes in their morphological interest and taxonomic isolation. The Australian flora includes species growing in a wide range of climatic conditions from the high rainfall areas of the south-west, where the giant blue gums grow to a height of more than three hundred feet, to the arid regions bordering on the Nullabor and central plains where vegetation may be said to flourish although it must endure an erratic rainfall that averages seven inches or less yearly. It is under these latter conditions that one encounters the amazing examples of homomorphy where species of many unrelated families appear remarkably alike until production of flowers discloses their individuality.

During the period of the Second World War, Captain and Mrs. McEacharn were forced to leave their famous garden, the Villa Taranto in Italy, when that country entered the War. They occupjed the time of their enforced exile in Australia, where they collected seeds assiduously for the Royal Botanic Gardens, Kew. The outcome was a collection of several hundreds of species, including a very large number not previously in cultivation. The difficulty of growing many species from the Antipodes is notorious, especially in the early stages; nevertheless, plants of the majority have been successfully raised, including many Proteaceæ.

The very crowded conditions in the existing Temperate House at Kew, despite its large size, have necessitated further accommodation and a new house to provide for these valuable additions. Such is now in course of construction and it is expected to be completed by next June. It will be about ninety feet long by some fifty feet in width and will permit the growth of specimens in the central beds nearly thirty feet in height. By the use of aluminium it is hoped to ensure a more adequate illumination than the utilization of a timber framework permits. 